\title{
Preface to the 20I I Edition
}

The Gothic Enterprise was first published in 2003. I wrote it with an audience in mind of those nonspecialist enthusiasts who visit and read about Europe's great medieval Gothic cathedrals, and I have heard from scores of such readers in the years since. My inspiration grew out of experiences I had while teaching courses about cathedrals in the Stanford Continuing Studies Program; leading tours of some of the great churches throughout the south and west of England with my wife, Julia Fremon; and paying visits with her to famous cathedrals elsewhere in England and Wales, France, Sweden, Spain, and cities in eastern and central Europe. In connection with these visits we read some of the standard histories about each of the buildings we were about to see, later often supplemented by the excellent guidebooks that cathedral bookshops sell. We find these latter sources quite informative, and they have always added greatly to our enjoyment of the experience of visiting each cathedral.

That said, the available sources do not always answer all of the questions that people who have joined our tours ask themselves while visiting a Chartres, a Canterbury, a Notre Dame, a Westminster Abbey, a Salisbury, or any of the other hundreds of such great churches of western and central Europe. While standing in awe of their astounding beauty, one cannot help but wonder how people living under the unforgiving conditions of daily life during the Middle Ages were able to initiate and ultimately complete such mag- 
nificent and audacious architectural works. What inspired them to want to do this? Why would anyone consider it a worthwhile use of the scarce liquid capital available at the time to invest so much of it in buildings that effectively did not produce anything?

Additional questions occur to the nonspecialists of our acquaintance, some so elementary that they may even feel uneasy asking about matters that specialists largely take for granted as unproblematic. Though most of us certainly recognize a Gothic cathedral when we see one, we are less sure we understand what sort of cultural artifact the Gothic cathedral actually is. Who used it, and for what? Why was it designed and laid out as it was? Throughout human history, people have worshipped gods, but why did those living during the Middle Ages believe they needed such grand spaces in which to do so? It is understandable that the devout might wish to set aside special places in which to venerate God, but why not simply mark off the ground around an open space, designate it as sacred, and pray there? What reason could there be for enclosing such spaces with soaring arches and adorned vaults? Why was interior light so important, particularly when sunlight was so readily and freely available outdoors? This book answers these and related questions, providing the interested nonspecialist with a basic guide to understanding the medieval Gothic cathedral as a type of cultural object.

I wrote The Gothic Enterprise with a second purpose in mind, prompted in part by the presentation of medieval cathedrals and great abbey churches in much of the existing scholarly work. Books about the great cathedral churches at, say, Wells, Amiens, Beauvais, Winchester, Durham, Canterbury, or Notre Dame recount the histories of these great churches one building at a time, as it were. Other studies analyze in impressive detail individual components of single cathedrals or other great churches - their chapels, tombs, stained glass windows, capitals, vaults, buttresses, altars, choir screens, towers and spires, statuary, cloisters, graveyards, undercrofts, and so on. These are useful approaches to advancing knowledge about the 
building of specific Gothic cathedrals, but they can leave the nonspecialist reader (and occasionally the trained specialist) with the misimpression that each individual cathedral or great abbey church is a sui generis creation. They also imply that one can fully understand such a structure without reference to others that were being built at the same time. Too often, while recounting the histories of individual cathedrals and great churches, scholarly works mention in passing only the scantest details about the larger social, political, religious, and cultural contexts out of which the impetus to build each one grew.

The written accounts of Salisbury Cathedral that I reference throughout this book illustrate this point. They present in impressive detail information about all aspects of this particular cathedral: who the presiding bishop was when work began; the names of successive master builders who oversaw its construction; the phases and dates of the building campaigns that led to its completion; how it was built; the volume of stone, lead, timber, and stained glass that went into its creation; where the raw materials came from and how they were transported to the site; and so on. But mentioned only in passing (and sometimes not at all) is the fact that during the period when Salisbury Cathedral was being built, I 220 to circa I300, important and equally ambitious building campaigns were simultaneously under way at Westminster Abbey, Winchester, Wells, Glastonbury Abbey, Canterbury, Gloucester, and other locations near and far. All of these projects were part of a large social movement that swept across western and central Europe beginning in the third decade of the twelfth century and continuing in fits and starts for the next four hundred years. I call this movement the Gothic enterprise and argue that it has much to tell us about why Salisbury or any other Gothic cathedral was built in the first place, and how. I do not wish to imply that these facts are unknown to those who have written the standard histories of Salisbury, but only to say that developments in neighboring cathedrals at the time form a part of the taken-forgranted canvas on which they paint their picture of this particular 
great church. My second main intention in writing this book, then, has been to bring to the foreground of our thinking about gothic cathedrals the larger context in which they were built and to make that context integral to the story of each one.

In the eight years since The Gothic Enterprise first appeared, scholars have produced excellent work on medieval cathedrals at a prodigious rate. This has deepened our understanding of individual buildings, revised some of the timelines for particular projects, and shed interesting new light on where certain materials came from and other construction details. I will not attempt to review this corpus here, but I offer some examples for those who may be interested in learning more about this work. ${ }^{1}$ There is, however, one book that deserves special mention, because it speaks so eloquently to an issue that lies at the very heart of any comprehensive analysis of Gothic cathedral-building during the Middle Ages.

The Edifice Complex, by Deyan Sudjic, is about why people throughout the ages have undertaken programs of monumental building. Sudjic, the architecture critic for the London newspaper the Observer, argues that cathedrals, like other forms of monumental structures, are expressions of an impulse he terms "the edifice complex," whereby those aspiring to power employ architecture to advance their control over others and create a permanent place for themselves in the historical record. The quest for power is hardly the sole motive behind Gothic cathedral-building projects, but by the same token, it is scarcely irrelevant to understanding them. The great value of Sudjic's book is that it not only invites us to think about medieval cathedrals in a larger context of political, cultural, and social power but also reminds us that they represent yet one more expression of an impulse that has been part of human history since history began.

Perhaps reflecting the impulse to build them, cathedrals still exert a strong pull. According to the website of Canterbury Cathedral, more than one million people visit it annually, a daily average of more than twenty-seven hundred people. Notre Dame Cathedral in Paris claims some thirteen million visitors each year, working out to a daily 
average of more than thirty-five thousand, and its website says that as many as fifty thousand people appear on key religious holidays. The website for York Minster estimates that cathedral's annual volume of visitors at one million, and nearby Durham Cathedral claims six hundred thousand visitors each year. The annual numbers of visitors to other great cathedrals of England include: St. Paul's in London, 2,000,०००; Westminster Abbey, I,০০০,০০০; Winchester, 500,000; Wells, 450,000; Norwich, 300,000; Lincoln, 250,000; Salisbury, 250,000; Ely, 200,000; and Manchester, 70,000. ${ }^{2}$

Annual counts of visitors are one measure of the powerful impact medieval cathedrals continue to have on people living today; another is the number and great popularity of books and television programs in which they play a prominent role. There are several book series, some turned into TV shows, about cathedrals and other great churches, including Anthony Trollope's Chronicles of Barsetshire, Paul Doherty's The Sorrowful Mysteries of Brother Athelstan, and Edith Pargeter's The Heaven Tree Trilogy and Cadfael Chronicles (the latter written under the pen name Ellis Peters). One of the members of our seminar group, Elaine Kreigh, is as avid a consumer of fiction set in medieval England as we know. In response to my request for a list of some of her favorites, she mentioned Edward Rutherford's popular books London (2002) and Sarum (2004), large sections of which are devoted to recounting Thomas à Becket's martyrdom at Canterbury and the building of Salisbury Cathedral in the thirteenth century, respectively. Other titles on her list include William Golding's The Spire, T. S. Eliot's Murder in the Cathedral, and, of course, Ken Follett's The Pillars of the Earth. Set in twelfthcentury England, Follett's riveting account of the building of the fictional cathedral of Kingsbridge has sold eighteen million copies worldwide since it first appeared in 1989, helped in part no doubt by its selection by the Oprah Winfrey Book Club. It has been made into a miniseries, being aired as I write this and viewed by millions of people. Follett followed Pillars with an increasingly popular sequel, World without End.

Since this book was first published I have continued to benefit 
from and value the colleagueship of members of the Sarum Seminar and other cathedral enthusiasts who regularly furnish me with details of their visits to the Gothic great churches of Europe. I wish to again thank them for their support and encouragement as I have pursued this and related projects. Above all, I continue to owe an enormous debt of gratitude to my wife, Julia Fremon, who has been with me on every step of my journey into the world of medieval cathedral-building.

\section{NOTES}

I. Recent books and articles on medieval architecture include James Ackerman, "The Origins of Architectural Drawings in the Middle Ages and Renaissance"; Carl Barnes, The Portfolio of Villard de Honnecourt; Robert Bork, The Geometry of Creation; Bork, William Clark, and Abby McGehee, eds., New Approaches to Medieval Architecture; Alexander Gajewski and Zoe Opacic, eds., The Year 1300 and the Creation of a New European Architecture; Evelyn Lane, Elizabeth Pastan, and Ellen Shortell, eds., The Four Modes of Seeing; Arnold Pacey, Medieval Architectural Drawing; Tim Tatton-Brown, "Canterbury and the Architecture of Pilgrimage Shrines in England"; Tatton-Brown and John Crook, The English Cathedral; Rolf Toman, ed., and Achim Bednorz, photographer, Gothic: Architecture-Sculpture-Painting; and Christopher Wilson, The Gothic Cathedral. Recent books and articles about individual cathedrals include Philip Ball, Universe of Stone; Bork, "Plan B and the Geometry of Façade Design at Strasbourg Cathedral, I252-I350"; Ute Engel, Worcester Cathedral, an Architectural History; and Nicholas Orme, Exeter Cathedral, the First Thousand Years, 400-2550. For the most up-to-date research on Salisbury Cathedral, see Brian Kemp and Tatton-Brown, "The Date of the Cloister of Salisbury Cathedral"; Matthew Reeve, Thirteenth-Century Wall Paintings of Salisbury Cathedral; TattonBrown, "The Salisbury Cathedral Consecration Crosses"; Tatton-Brown, "The Fabric of the Westminster Chapter House: Filling in the Gaps from Salisbury"; and Tatton-Brown, Salisbury Cathedral. For medieval Salisbury, see Christian Frost, Time, Space and Order; and Tatton-Brown, "Reconstructing the Medieval Landscape around Salisbury." For living conditions during medieval times, see Emily Cockayne, Hubbub; A. Roger Ekirch, At Day's Close; and Brian Fagan, The Great Warming. 
2. See www.canterbury-cathedral.org/; www.cathedraledeparis.com/-English-; www.yorkminster.org/; www.durhamcathedral.co.uk/; www.stpauls.co.uk/; www.westminster-abbey.org/; http://winchester-cathedral.org.uk/; www .wellscathedral.org.uk/; www.cathedral.org.uk/; www.lincolncathedral .com/; www.salisburycathedral.org.uk/; www.elycathedral.org/; and www .manchestercathedral.org/. 
This page intentionally left blank 